\title{
Structural damages of L'Aquila (Italy) earthquake
}

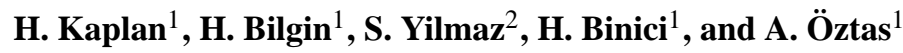 \\ ${ }^{1}$ Epoka University, Engineering and Architecture Faculty, Department of Civil Engineering, Tirana, Albania \\ ${ }^{2}$ Pamukkale, Engineering Faculty, Department of Civil Engineering, Denizli, Tukey
}

Received: 28 September 2009 - Revised: 10 February 2010 - Accepted: 24 February 2010 - Published: 16 March 2010

\begin{abstract}
On 6 April 2009 an earthquake of magnitude 6.3 occurred in L'Aquila city, Italy. In the city center and surrounding villages many masonry and reinforced concrete (RC) buildings were heavily damaged or collapsed. After the earthquake, the inspection carried out in the region provided relevant results concerning the quality of the materials, method of construction and the performance of the structures. The region was initially inhabited in the 13th century and has many historic structures. The main structural materials are unreinforced masonry (URM) composed of rubble stone, brick, and hollow clay tile. Masonry units suffered the worst damage. Wood flooring systems and corrugated steel roofs are common in URM buildings. Moreover, unconfined gable walls, excessive wall thicknesses without connection with each other are among the most common deficiencies of poorly constructed masonry structures. These walls caused an increase in earthquake loads. The quality of the materials and the construction were not in accordance with the standards. On the other hand, several modern, non-ductile concrete frame buildings have collapsed. Poor concrete quality and poor reinforcement detailing caused damage in reinforced concrete structures. Furthermore, many structural deficiencies such as non-ductile detailing, strong beams-weak columns and were commonly observed. In this paper, reasons why the buildings were damaged in the 6 April 2009 earthquake in L'Aquila, Italy are given. Some suggestions are made to prevent such disasters in the future.
\end{abstract}

\section{Introduction}

L'Aquila has been assessed as an area of relatively high seismic hazard (Slejko et al., 1998; Rebezet al., 2001). Based on a report on historical earthquakes, the city was struck by earthquakes in 1315, 1349, 1452, 1501, 1646, 1703, and 1706 (Boschi et al., 1999). The L'Aquila earthquake was the

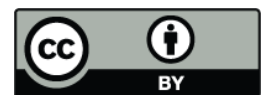

Correspondence to: $\mathrm{H}$. Binici

(hbinici@epoka.edu.al) most deadly in Italy since 1980 Napoli earthquake. The seismic hazard map and the shake map of L'Aquila Earthquake can be seen in Fig. 1 (USGS, 2010).

An earthquake of 6.3 moment magnitude occurred in the central Italian region of Abruzzo on 6 April 2009, following a series of minor shakings since January 2009 , including a 4.0-magnitude one on 30 March (USGS, 2010). The majority of the damage occurred in the medieval city of L'Aquila and the surrounding villages. The depth of the earthquake was given as $8.8 \mathrm{~km}$ by the US Geological Survey. Epicenter coordinates of the earthquake were $42.334^{\circ} \mathrm{N}$ and $13.334^{\circ} \mathrm{E}$ (USGS, 2010). This earthquake was caused by the movement on a NW-SE trending normal fault according to moment tensor solutions (USGS, 2010). This moderate earthquake occurred in a densely populated region with one major city and its districts and villages accommodating over 70000 people.

Damages to buildings were severe and widespread. Eventually, 306 people died, with some 1500 people injured and thousands left homeless. A large number of structures comprising reinforced concrete, masonry and historical buildings were heavily damaged or collapsed.

According to official reports, 15000 buildings were severely damaged or collapsed. Nearly, $70 \%$ of the buildings in L'Aquila were either damaged or severely destroyed (Earthqauke Engineering Research Institute, EERI ${ }^{1}$ ). It was observed that unreinforced masonry or reinforced concrete moment resisting frames with hollow clay tile infill partitions are the most popular structural systems in the region. The main structural materials are unreinforced masonry composed of rubble, stone, brick, and hollow clay tile. Moreover, observations revealed that the majority of the damages in L'Aquila were constricted to old masonry buildings (Fig. 2). However, many new RC buildings having non-ductile moment frames also collapsed. There are many events of infill wall damages which experienced either shear failure or outof-plane failure due to lack of anchors at the upper and bottom of the walls.

\footnotetext{
${ }^{1} \mathrm{http}: / / w w w . e e r i . o r g /$ site/reconnaissance-activities/69-italy/ 544-m-63-laquila-italy
}

Published by Copernicus Publications on behalf of the European Geosciences Union. 


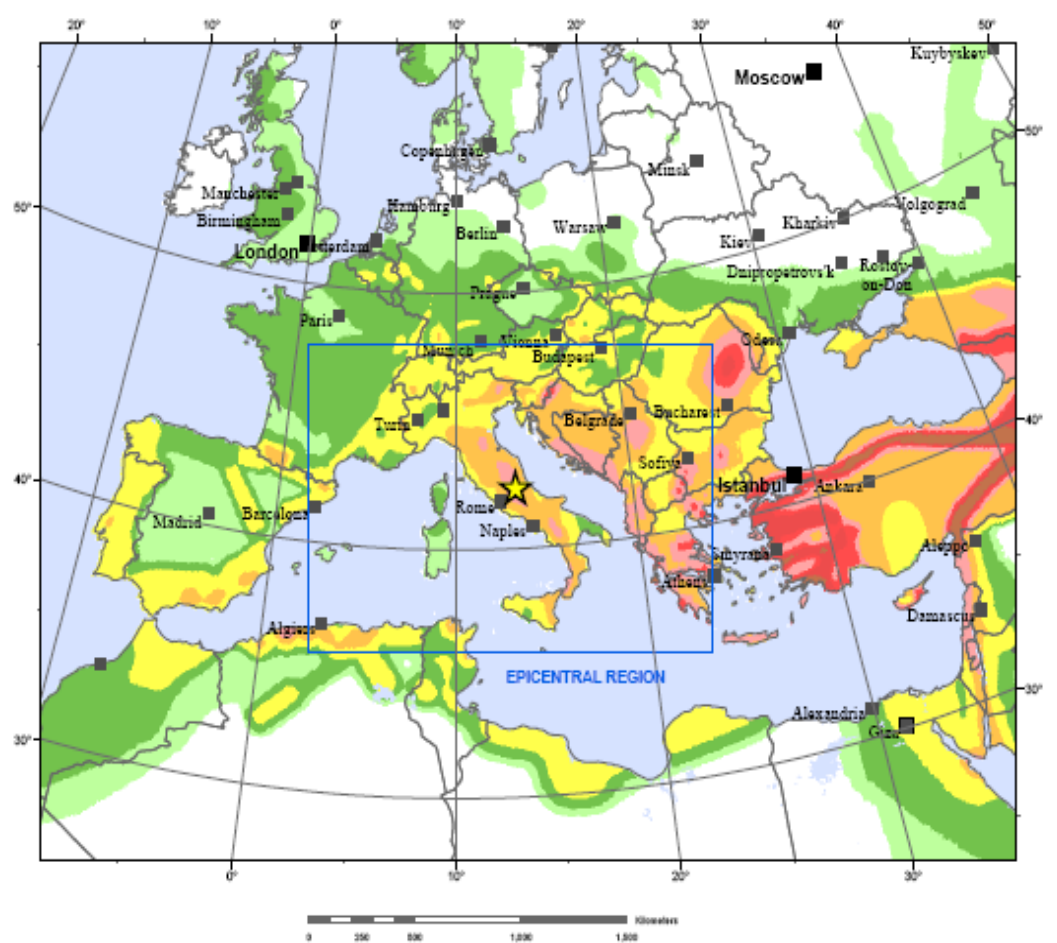

Peak Ground Acceleration in m/sec" 2

(a)
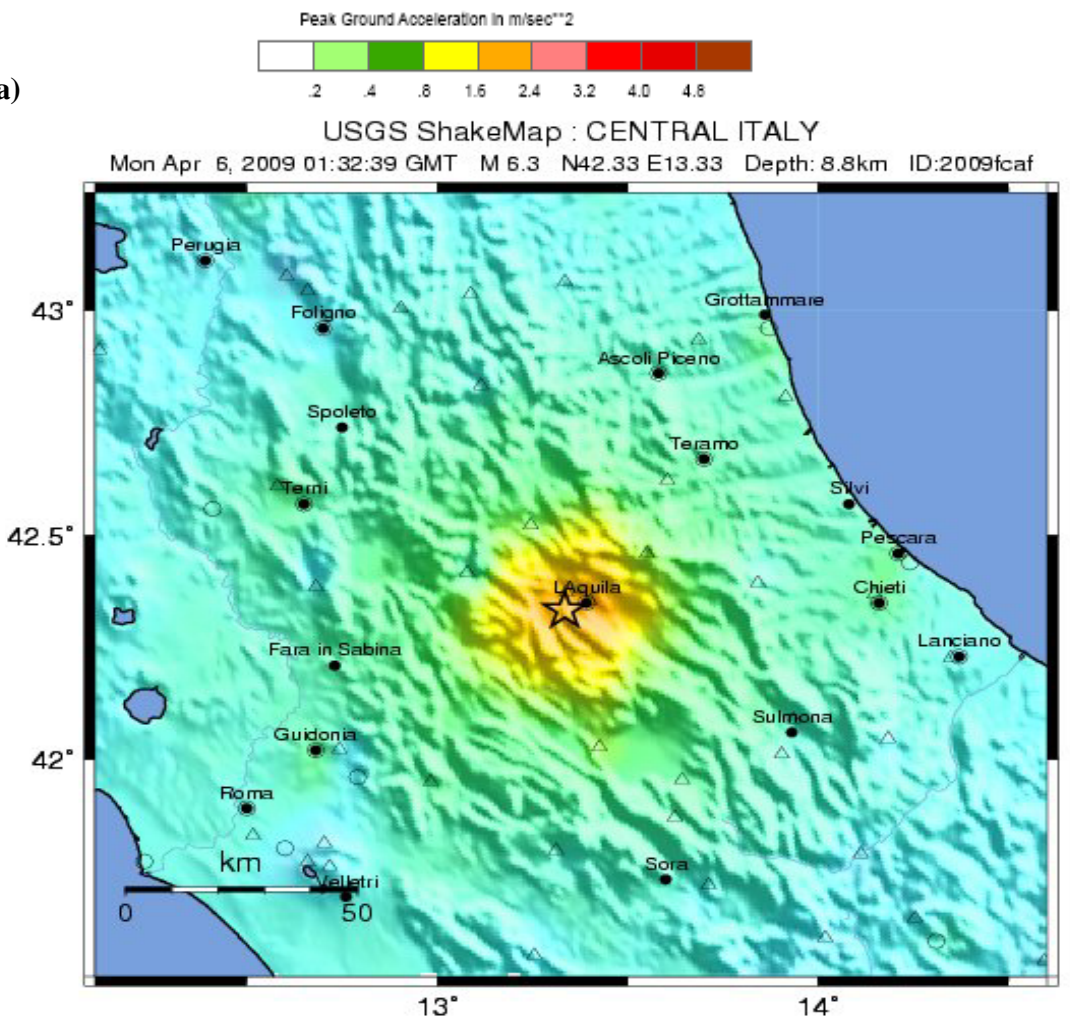

Map Version 6 Processed Thu Apr 9, 200905:47:32 PM MDT - NOT REVIEWED BY HUMAN

\begin{tabular}{|c|c|c|c|c|c|c|c|c|c|}
\hline $\begin{array}{l}\text { PEACEEEED } \\
\text { SHAKIHE }\end{array}$ & Not felt & Weak & Light & Moderate & Strong & Very strong & Severe & Violent & Extreme \\
\hline $\begin{array}{l}\text { POTENAIALL } \\
\text { DAMGEE }\end{array}$ & none & none & none & Very ight & Light & Moderate & Iboderale/Heavy & Heavy & Very Heavy \\
\hline PEAK ACC $(\%(\%)$ & $<.17$ & $.17-1.4$ & $1.4-3.9$ & $3.9-9.2$ & $9.2-18$ & $18-34$ & $34-65$ & 65-124 & $>124$ \\
\hline PEAK VEL(cms) & $<0.1$ & $0.1-1.1$ & $1.1-3.4$ & $3.4-8.1$ & $8.1-16$ & $16-31$ & $31-60$ & $80-116$ & $>116$ \\
\hline $\begin{array}{l}\text { IHSTRUMENTAL } \\
\text { ITETESTY }\end{array}$ & I & It-III & IV & v & VI & VII & VIII & IX & $x_{+}$ \\
\hline
\end{tabular}

(b)

Fig. 1. (a) Seismic Hazard Map (Peak Ground Acceleration $\left(\mathrm{m} / \mathrm{s}^{2}\right.$ ) with $10 \%$ Probability of Exceedance in 50 years). (b) Shake map of the L'Aquila Earthquake (USGS, 2010). 

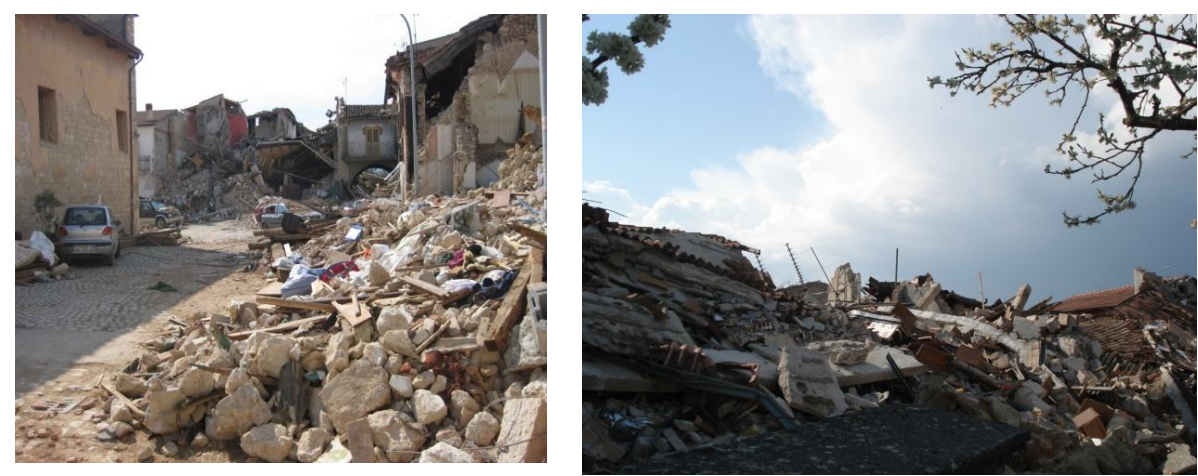

Fig. 2. A general view of building damage in Onna; collapsed and severely damaged residential buildings.

Table 1. Strong motion characteristics.

\begin{tabular}{|c|c|c|c|c|c|c|c|}
\hline Station code & Coordinates & Site class & $\begin{array}{l}\text { Epicentral distance } \\
(\mathrm{km})\end{array}$ & $\begin{array}{l}\text { PGA } \\
\left(\mathrm{cm} / \mathrm{s}^{2}\right)\end{array}$ & $\begin{array}{l}\text { PGV } \\
(\mathrm{cm} / \mathrm{s})\end{array}$ & $\begin{array}{l}\text { Arias intensity } \\
(\mathrm{cm} / \mathrm{s})\end{array}$ & $\begin{array}{l}\text { Housner intensity } \\
(\mathrm{cm})\end{array}$ \\
\hline AQM & $\begin{array}{l}42.379^{\circ} \mathrm{N} \\
13.349^{\circ} \mathrm{E}\end{array}$ & A & 5.2 & $\begin{array}{l}1000 \\
\text { (saturated) }\end{array}$ & 42.18 & 435.4 & 90.1 \\
\hline AQV & $\begin{array}{l}42.377^{\circ} \mathrm{N} \\
13.344^{\circ} \mathrm{E}\end{array}$ & B & 4.9 & 646.1 & 42.83 & 285.7 & 94.5 \\
\hline AQG & $\begin{array}{l}42.373^{\circ} \mathrm{N} \\
13.337^{\circ} \mathrm{E}\end{array}$ & A & 4.4 & 506.9 & 35.54 & 137.0 & 92.2 \\
\hline AQA & $\begin{array}{l}42.376^{\circ} \mathrm{N} \\
13.339^{\circ} \mathrm{E}\end{array}$ & B & 4.6 & 435.6 & 32.03 & 175.0 & 86.1 \\
\hline AQK & $\begin{array}{l}42.345^{\circ} \mathrm{N} \\
13.401^{\circ} \mathrm{E}\end{array}$ & B & 5.6 & 347.2 & 36.21 & 128.9 & 68.1 \\
\hline AQU & $\begin{array}{l}42.354^{\circ} \mathrm{N} \\
13.402^{\circ} \mathrm{E}\end{array}$ & B & 5.8 & 309.5 & 35.00 & 71.0 & 78.0 \\
\hline GSA & $\begin{array}{l}42.421^{\circ} \mathrm{N} \\
13.519^{\circ} \mathrm{E}\end{array}$ & A & 14.1 & 149.1 & 9.84 & 44.0 & 17.8 \\
\hline
\end{tabular}

This paper describes different types of structural damages that were observed by the authors. The reasons of the structural damages are discussed and placed into context with some suggestions.

\section{Evaluation of strong ground motion records and response spectra}

L'Aquila Earthquake was caused by the rupture of the Paganica fault, which is a normal fault. According to Italian National Institute of Geophysics and Volcanology (INGV) the event had a magnitude of $M_{\mathrm{w}}=6.3\left(M_{\mathrm{l}}=5.8\right)$ and a focal depth of $8.8 \mathrm{~km}$.

The earthquake has been recorded by 58 stations operated by Italian Strong Motion Network. Besides, 113 seismometers of the INGV network recorded the earthquake. Table 1 shows the strong motion record characteristics with PGA values greater than $0.1 \mathrm{~g}$.
The table depicts quite high PGA values with respect to the magnitude of the event. For AQM station, PGA has also saturated, which makes it impossible to use the record. Horizontal components of the motion are given in Fig. 3 for five stations. Strong shaking duration of the earthquake $(90 \%$ of the energy) was less than $10 \mathrm{~s}$. Besides, $60 \%$ of the energy was exerted on the buildings within 3-5 s (Çelebi et al., 2010). Therefore, it can be categorized as a short event with high PGA values that are capable of producing high spectral accelerations. It is certain that a prolonged period of shaking with high accelerations would cause a heavier damage profile for buildings.

Figure 4 compares spectral acceleration values of each record and the average of them with the current design spectrum of the Italian Code (NTC2008) for rock type soils and that of 1996 Code for Category 2. The current code has greater spectral accelerations with respect to the older code. However, most of the buildings were not designed accord- 


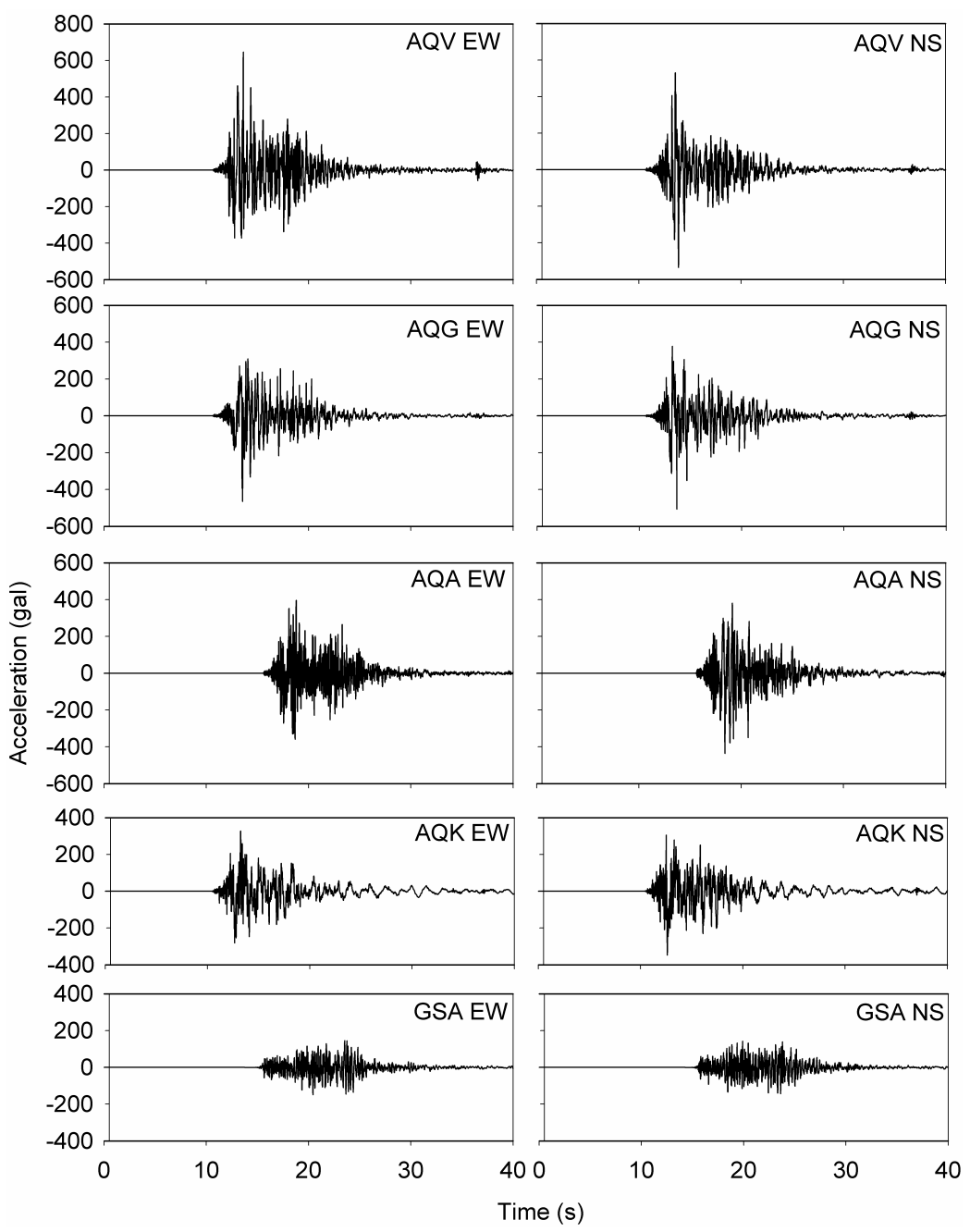

Fig. 3. Corrected acceleration records for five stations with PGA $>0.1 \mathrm{~g}$ (time not synchronized).

ing to 2008 code. Moreover, many of the buildings were non-engineered. Nevertheless, response spectra have much higher acceleration values than both codes especially for periods less than $1.0 \mathrm{~s}$. This figure clearly shows that buildings were exposed to seismic forces higher than the expected design forces. The average spectrum of 10 strong motion components almost doubles the spectrum of 1996 code for $\mathrm{T}<0.5 \mathrm{~s}$. According to these records, the earthquake can be classified as a strong one.

Elastic and inelastic demand spectra are plotted in Fig. 5. The inelastic demand level is also a good indicator of destructive potential of the earthquake. Even for a ductility level of 7, inelastic strength demand reaches to $40 \%$ of the total building weight, which includes dead loads and a fraction of live loads especially for small periods. On the other hand, many of the non-engineered buildings have low ductility; therefore many buildings are excited by inelastic seismic demands reaches up to $50 \%$ of their weight or more.

\section{Structural damages to reinforced concrete buildings}

Damages in RC structures may be classified into two groups as out of plane collapse of non-structural walls and brittle failures of RC frame members. Many of the collapses of reinforced concrete structures during the earthquake could be attributed to the poor quality construction and the use of non-ductile detailing. Inspection of collapsed and damaged buildings revealed that very little or no seismic design had been implemented during the design and construction of reinforced concrete moment-frame systems. In RC buildings, shear walls should be used to resist earthquake excitations. It was observed that shear walls were not used in multistory RC buildings.

Many RC buildings had been constructed with two partition walls at sides of the buildings. The inner one is constructed as an infill wall. However, the outer one was constructed to surround beams and columns for isolation 


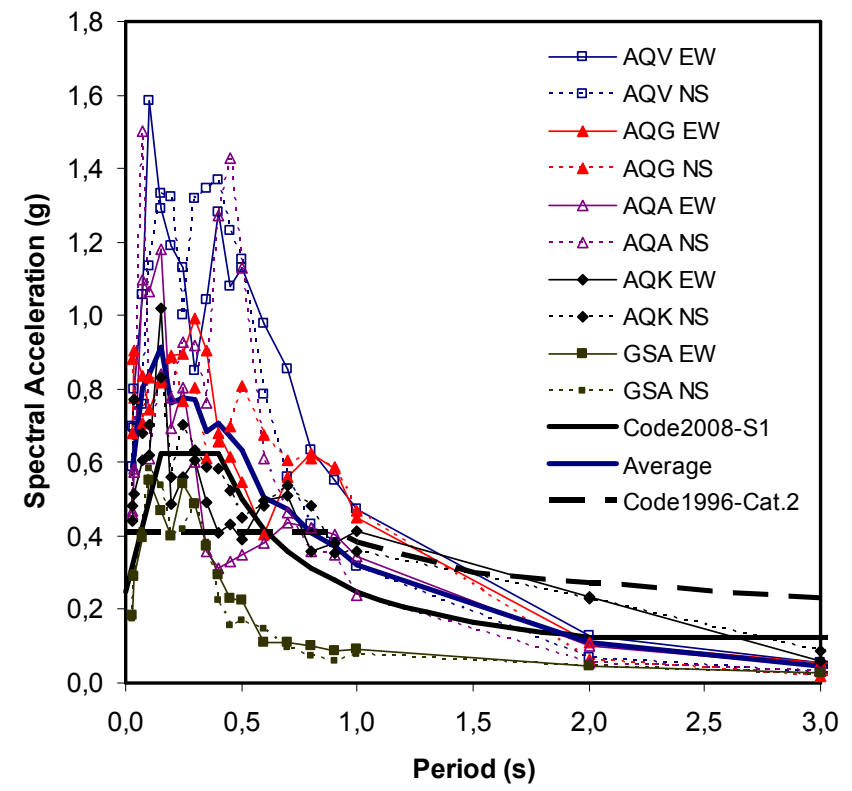

Fig. 4. Response spectra of the records from 5 stations for $5 \%$ damping and comparison with NTS design spectrum.

purposes. Although it is a good solution to prevent heat bridges, unrestrained walls had low out-of-plane resistance. Many such walls collapsed and caused important damages (Fig. 6).

Isolating side walls were not anchored to the structural framing with masonry ties. Infill walls were built in contact with the structural framing and increase the base shear capacity of the framing system. Damage to infill masonry walls was concentrated in the lower stories of buildings because of higher demands on the story shear forces of the moment-frame-infill wall system. Figure $6 \mathrm{~b}$ and c illustrates typical damage to infill walls in two buildings in the center of L'Aquila.

Poor quality of concrete was observed many RC buildings (Fig. 7). Poor detailing of RC sections and joints have caused structural elements to behave in a brittle manner and end up with shear type failures. Figure 8a depicts shear failure in beam-column joints and column shear failures. Besides, longitudinal reinforcements also buckled due to the lack of transverse reinforcement in the joint. On the other hand, transverse reinforcement spacing was measured to be up to $40 \mathrm{~cm}$ in columns in the damaged RC buildings. No transverse reinforcement was used in column-beam connection joints of many buildings. Shear failures caused by inadequate transverse reinforcement can be seen in Fig. 8b. Inadequate detailing of transverse reinforcement caused not only shear failures but also buckling of longitudinal reinforcement in plastic hinge regions. This also led to a brittle mode of failure. Such a typical damage is shown in Fig. 9.

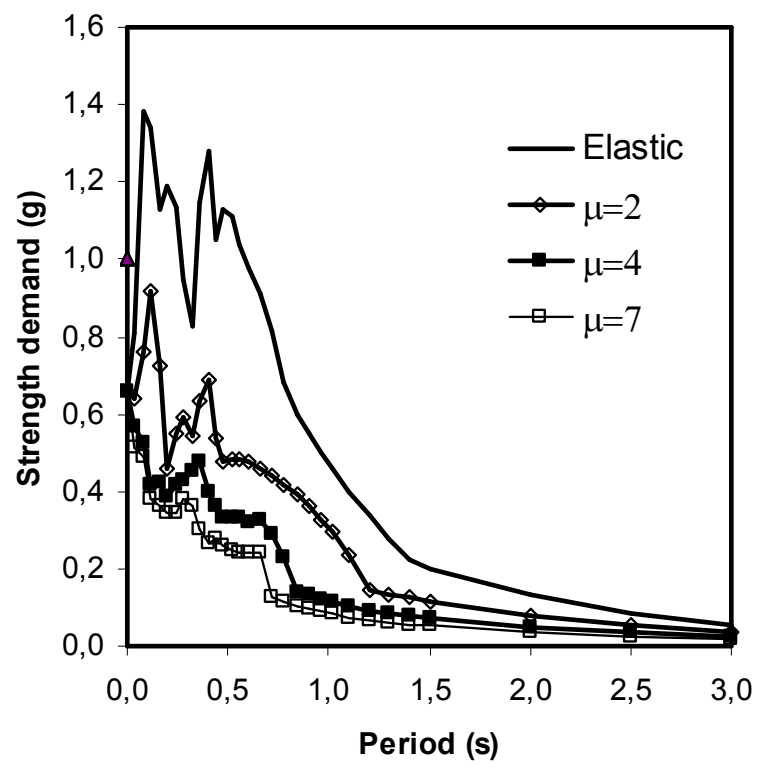

Fig. 5. Inelastic demand spectrum for AQV-EW record for different ductility levels.

Moment frames require careful detailing and excellent construction quality to achieve the intended level of performance during earthquakes. In L'Aquila earthquake, it was observed that detailing of RC buildings was very poor.

\section{Structural damages to masonry buildings}

Masonry buildings, the oldest type of structural systems, are still popular especially for low-storey buildings. Despite their complex seismic behavior, seismic resistant masonry buildings are a well-known topic among structural engineers. Lessons drawn from investigations of damaged masonry buildings after past earthquakes (Kaplan et al., 2004, 2008; Binici, 2007; Bayraktar et al., 2007; Ramazi and Jigheh, 2006) greatly contributed to the knowledge.

L'Aquila earthquake served as a good open-laboratory for damaged masonry buildings. Some of those buildings had historical characteristics. Many of the damaged historical monumental buildings were stone and rubble stone masonry having low construction quality. Similarly, other masonry buildings in rural settlement areas of L'Aquila were also usually constructed by rubble stone and heavy blocks usually, which can be easily available around settlement areas (Fig. 10). Many of these masonry buildings were nonengineered and were not earthquake resistant.

Unconnected outer and inner wythes are given in Fig. 11. These types of deficiencies lead to out-of-plane failures. Typical wall section observed at many damaged walls is compared with an earthquake resistant section in Fig. 11, where lack of connection between outer and inner wythes can be seen. 

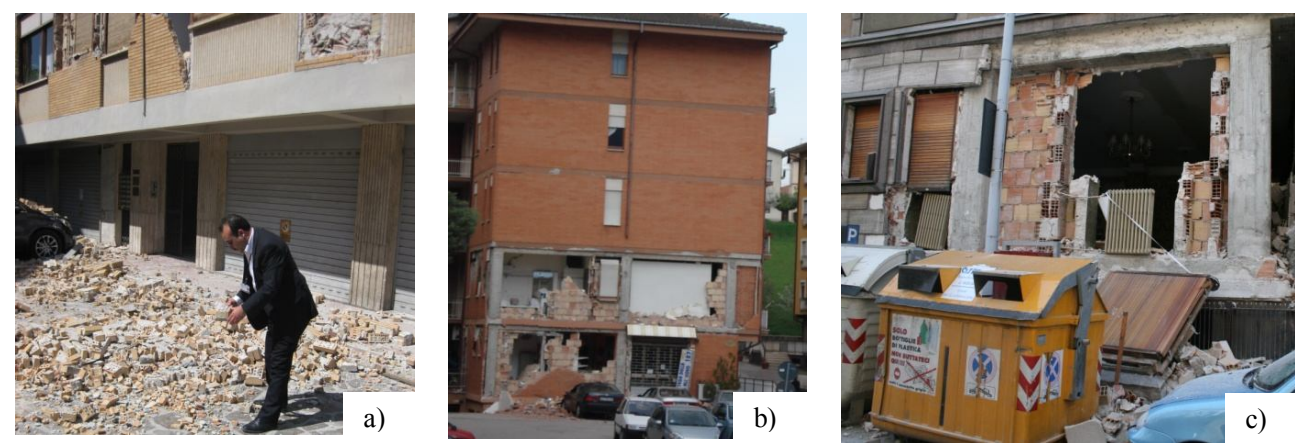

Fig. 6. (a) Typical hollow clay tile used in infill walls, (b-c) severe infill wall damages.
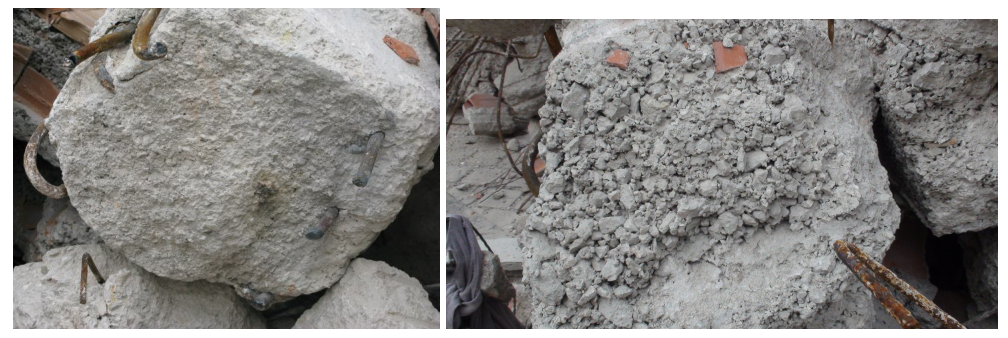

Fig. 7. Aggregate used in concrete having no particle size distribution.
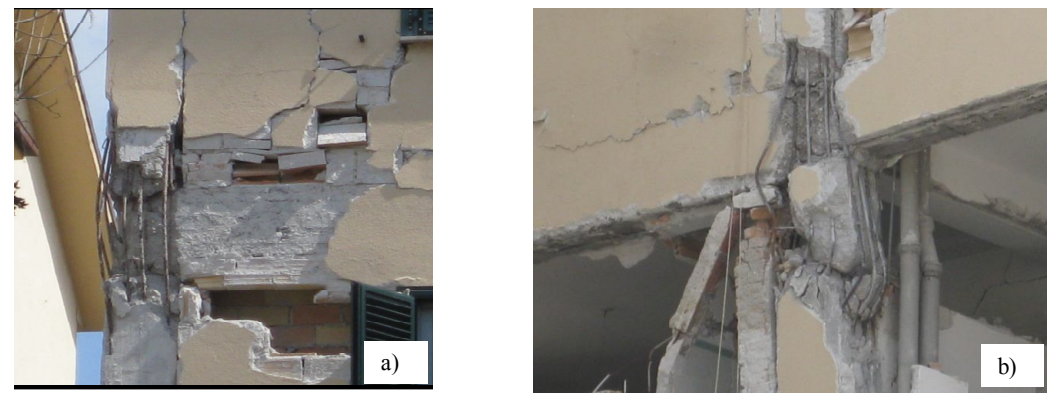

Fig. 8. (a) Shear failure in beam-column joints. (b) Shear failure of column and beam-column joint.

Another reason for out-of-plane failures are poorly connected crossing walls. In many cases, at corner points of the buildings, masonry units did not properly overlap to ensure an earthquake-resistant connection. This causes walls to be separated at initial stages of the quake. After that, out-ofplane failures were initiated due to poor restraining conditions. These types of damages are shown in Fig. 12.

Restraining effect of crossing walls was reduced by wall openings placed to close to the building corner. Such damages are given in Fig. 13. Window and door openings weaken the connection of crossing walls. If there was a greater ground-shake, next expected steps would be out-of-plane failure of those walls like in many other cases in L'Aquila.

Beside relatively new buildings, many historical churches collapsed or heavily damaged (Fig. 14). The Church of Santa Maria del Suffragio in L'Aquila was seriously damaged but the remains of PopeCelestino V that were kept inside were recovered from the basilica shortly after the earthquake. The dome of the Duomo of the Amine Sante also collapsed. The dome of this church was made of heavy rubble stone and wall thickness was excessive and improper.

\section{Results}

Although the magnitude of the event $\left(M_{\mathrm{w}} 6.3\right)$ with respect to its PGA values is quite low, it has caused extensive damages to many reinforced concrete and masonry buildings. The amplitudes of the ground shaking affecting L'Aquila settlements range between $0.3 \mathrm{~g}-1.0 \mathrm{~g}$. As indicated by the response spectra, the frequency content of the recorded motions was in the range of $0.1 \mathrm{~s}-1.0 \mathrm{~s}$, which have resemblance 

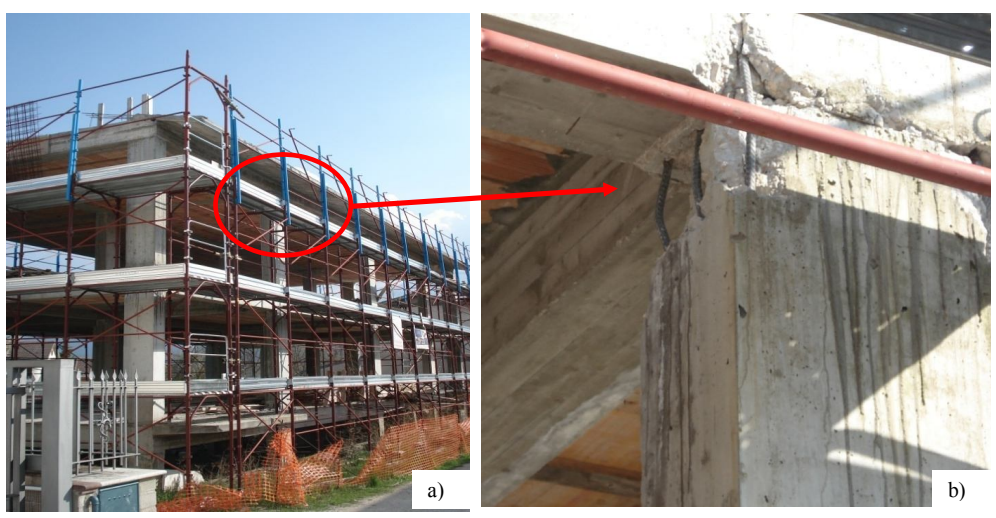

Fig. 9. (a) Moment frame under construction. (b) Buckling of the reinforcement in plastic hinge regions.
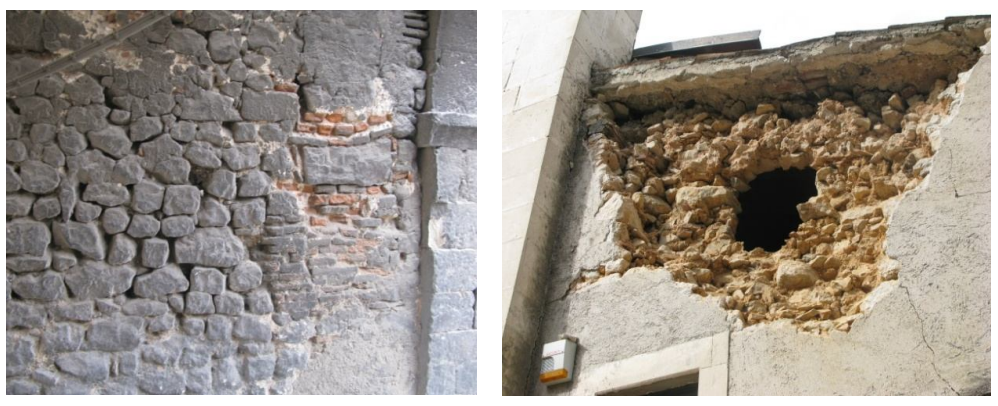

Fig. 10. Bad profile of a damaged wall.

to the range of fundamental frequencies of the most buildings in the affected area. The experience provided by the L'Aquila earthquake shows that there is a significant gap between the requirements established by modern seismic codes and construction practice especially in rural areas. Besides poor construction practices and the use of non ductile seismic detailing, high spectral accelerations were the main reasons for most of the reinforced concrete building failures. Further reasons are as follows;

- It has been observed that the concrete quality was poor at many RC buildings and a significant percentage of RC buildings with limited ductility and deficient strength did not have the required lateral capacity to resist the ground shaking without damage.

- No shear walls were observed in the damaged RC buildings. The horizontal rigidity of the multi-storey $\mathrm{RC}$ buildings was not sufficient. Due to the existence of slender columns with brittle seismic behavior, these types of buildings were subjected to considerable damages.

- Transverse reinforcement was not detailed properly in most of the damaged columns. Poor detailing in beamcolumn joints was also frequently observed.

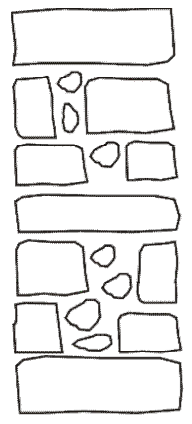

a)

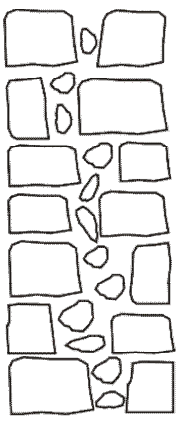

b)
Fig. 11. (a) Proper and (b) improper details.

- Non-structural walls of RC buildings were not properly restrained to the frame, and hence out-of-plane failures of those walls were observed in many RC buildings.

- In general, the external walls had two layers, within which there was isolation material. The external unanchored walls experienced major damages during this earthquake leading to out-of plane failures of them.

- Despite these negative effects, infill walls played a positive role in preventing several non-ductile framed structures from collapsing. However, this positive help was 

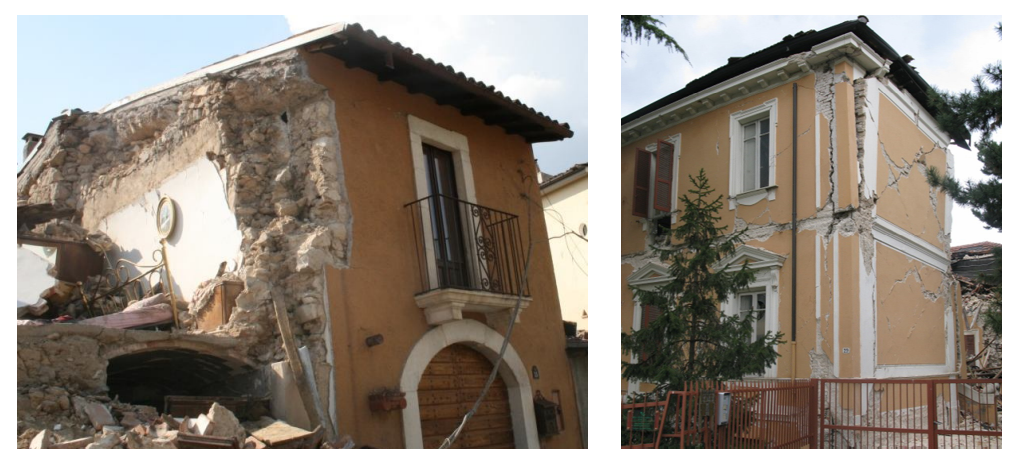

Fig. 12. Badly connected crossing walls causing out-of-plane failures.
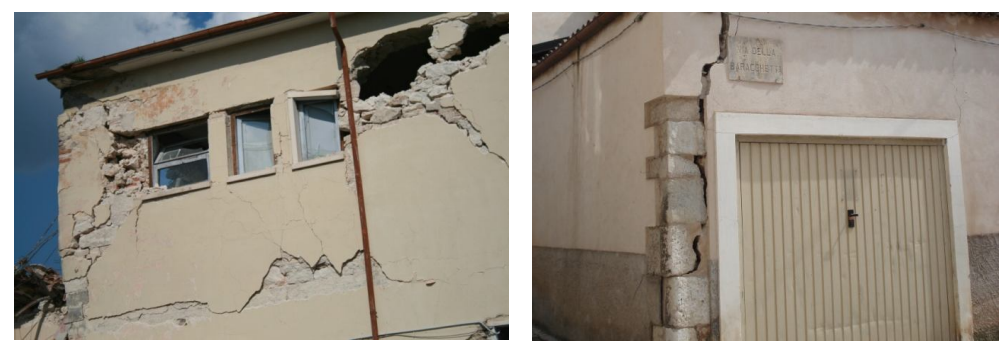

Fig. 13. Damages observed at connection of crossing walls.
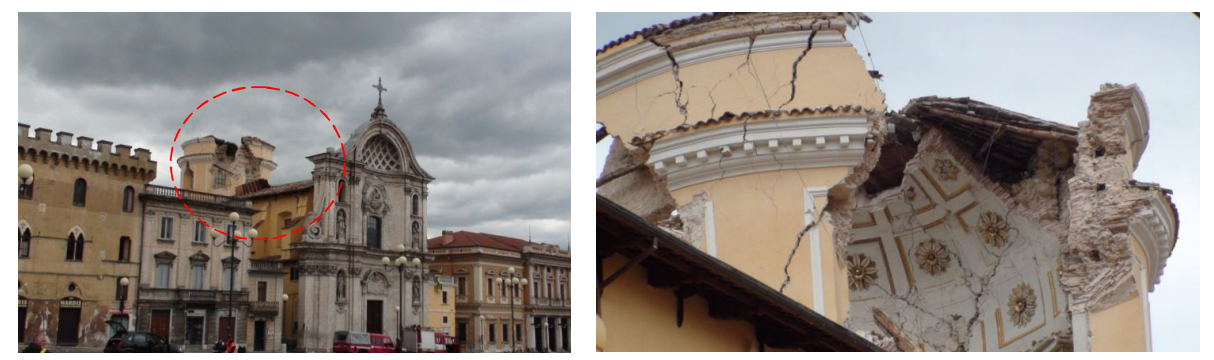

Fig. 14. Damages observed at connection of crossing walls.

sufficient to prevent many collapses because of the relatively short duration of ground shaking. It is certain that a prolonged period of shaking with high accelerations would cause a heavier damage profile for buildings.

Masonry structures also suffered out-of-plane failures. Many of these masonry buildings were constructed as rubble stone masonry in rural areas. Materials and construction techniques of these stone masonry buildings did not provide earthquake resistance to the buildings. Considering construction techniques of these buildings, the most important defects are listed below;

- The lack of interlocking elements between external and internal units of the wall section and lack of connection between crossing walls.
- The wall thickness and the floors were too thick. This increased the weight of the structure and therefore resulted in higher earthquake forces.

- The joining of rubble stones with mud and lack of interlocking walls caused damage of these buildings under the effect of the earthquake loads. Almost all of the walls of the masonry buildings were not appropriate to carry the earthquake loads.

- In joining the corners of the masonry buildings many mistakes were made. The interlocking walls were not connected properly.

- The percentage of the doors and windows was relatively high. The placement of the windows near the corners resulted in damages. 
- Due to lack of proper connection between the walls and roof in the roof level the structural response was different and damages were observed.

\section{Conclusions}

Generally, the structural performance of the buildings in the city center was not satisfactory. The main structural materials are URM composed of rubble stone, brick, and hollow clay tile. Masonry units suffered the worst damage. Several modern, non-ductile concrete frame buildings have collapsed. In reinforced concrete structures, many structural deficiencies such as non-ductile detailing, poor concrete quality, strong beams-weak columns were commonly observed.

Lack of ductility in older buildings (including historical) or newer buildings played a big role in collapse or the damage of these structures. The main conclusions drawn from this study are given below;

- In the cities under similar earthquake risk, the necessary precautions must be taken into consideration. In an anticipated earthquake, the potential for damage of masonry buildings is high. For these kinds of buildings a new retrofitting methodology must be proposed, which will not influence the functionality and will not disturb normal usage by the inhabitants.

- The RC buildings without shear walls can be practically retrofitted by adding external shear walls.

- In order to prevent the out of-plane failure of the external partition walls, aiming at isolating, a connection with the remaining inner wall must be provided as well as anchoring to the structural elements in order to prevent damages.

To sum up, thousands of existing structures designed and constructed in accordance with earlier or no seismic codes at all, are present in seismically active areas worldwide. These buildings must be properly retrofitted as soon as possible in order to prevent future loss of lives.

Acknowledgements. Authors thank for the support given by the Epoka University and Istituto Tevere for hosting and helping during the inspection of earthquake, as well as the fire service of Italy. Also authors express their deep gratitude to Massimo Sonetti for his sincere guidance during the site visit.

Edited by: M. E. Contadakis

Reviewed by: two anonymous referees

\section{References}

Bayraktar, A., Cokun, N., and Yalçin, A.: Damages of masonry buildings during the July 2, 2004 Doğubayazit (A ğri) earthquake in Turkey, Eng. Fail. Anal., 14, 147-57, 2007.

Binici, H.: March 12 and June 6, 2005 Bingöl-Karliova earthquakes and the damages caused by the material quality and low workmanship in the recent earthquakes, Eng. Fail. Anal., 14, 233-238, 2007.

Boschi, E., Guidoboni, E., Ferrari, G., Mariotti, D., Valensise, G., and Gasperini, P. (Eds.): Catalogue of Strong Italian Earthquakes from 461 B.C. to 1997, Ann. Geofis., 43, 609-868, 2000.

Çelebi, M., Bazzurro, P., Chiaraluce, L., Clemente, P., Decanini, L., DeSortis, A., Ellsworth, W., Gorini, A., Kalkan, E., Marcucci, S., Milana, C., Mollaioli, C., Olivieri, M., Rinaldis, D., Rovelli, A., Sabetta, F., and Stephens, C.: Recorded Motions of the Mw6.3 April 6, 2009 L'Aquila (Italy) Earthquake and Implications for Building Structural Damage, Earthquake Spectra, in press, 2010.

Kaplan, H., Yilmaz, S., Akyol, E., Sen, G., Tama, Y. S., Cetinkaya, N., Nohutcu, H., Binici, H., Atimtay, E., and Sarisin, A.: 29 October 2007, Çameli earthquake and structural damages at unreinforced masonry buildings, Nat. Hazards Earth Syst. Sci., 8, 919-926, 2008, http://www.nat-hazards-earth-syst-sci.net/8/919/2008/.

Kaplan, H., Ylmaz, S., Binici, H., Yazar, E., and Cetinkaya, N.: May 1, 2003 Turkey-Bingöl earthquake: damage in reinforced concrete structures, Eng. Fail. Anal., 11, 279-291, 2004.

Ramazi, H. and Jigheh, H. S.: The Bam (Iran) earthquake of December 26, 2003: From an engineering and seismological point of view, J. Asian Earth Sci., 27, 576-84, 2006.

Rebez, A., Sabetta, F., and Slejko, D.: New seismic hazard maps of the Italian territory, Gruppo Nazionale per la Difesa dai Terremoti, Servizio Seismico Nazionale, 2001

Slejko, D., Peruzza, L., and Rebez, A.: Seismic hazard maps of Italy, Ann. Geofis., 41, 183-214, 1998.

USGS: Preliminary Earthquake Report, US Geological Survey, National Earthqauke Information Center, World Data Center for Seismology, available at: http://earthquake.usgs.gov/eqcenter/ eqinthenews/2009/us2009fcaf/(last access: March 2010), 2010. 